ISLAMIC BANKING: Jurnal Pemikiran dan Pengembangan Perbankan Syariah, Volume 7 Nomor 2 Edisi Februari 2022

\title{
PERSPEKTIF PAJAK ATAS PENGARUH ASET PAJAK TANGGUHAN DAN UKURAN PERUSAHAAN TERHADAP MANAJEMEN LABA (PERUSAHAAN LISTING MANUFAKTUR 2018-2020)
}

\author{
Muhammad Faisal Akbar Ibrahimy \\ Mahasiswa Fakultas Administrasi Fiskal Universitas Indonesia \\ Email:m.faisal23@gmail.com \\ Gunadi \\ Fakultas Administrasi Fiskal Universitas Indonesia \\ Email: gunadi@gmail.com
}

\begin{abstract}
For the last decade, there has been many cases of earning management on Indonesia. This follow suits with the agency theory as management is trying to achieve their own personal goal. Management will try to manipulate the information on financial report thus doing earning management. Some of the widely used indicators to detect earning management are deferred tax asset and firm size. Firm size will be represented by total asset of the company. Deferred tax asset will be represented by asset depreciation. The purpose of this study is to examine the effect of Deferred tax asset and firm size on earning management. The result of this research will be studied deeper using interview technique. The research data show that both hypothesis are accepted. The statistic has determined that there are positive relation between deferred tax asset and firm size to earning management. Management used the depreciation method to increase profit or lower the tax obligation on that period. The bigger the firm means that there are bigger chances of earning management.
\end{abstract}

Keywords: Tax, Tax Assets, Company, Profit Management

\begin{abstract}
Abstrak
Dalam satu decade ke belakang, kasus manajemen laba banyak terjadi di Indonesia. Manajemen akan melakkan manipulasi pada laporan keuangan hingga akhirnya memanajemen keuntungan. Beberapa komponen yang sering digunakan untuk menjadi indicator dari manajemen laba adalah aset ukuran perusahaan dan pajak tangguhan. Ukuran perusahaan akan direpresentasikan oleh total aset. Aset pajak tangguhan akan direpresentasikan oleh depresiasi aset. Kemudian hasil penelitian ini akan ditelusuri lebih dalam dengan wawancara mendalam. Hasil penelitian menunjukan bahwa kedua hipotesis diterima. Hasil statisik menunjukan bahwa terdapat hubungan positif antara ukuran perusahaan serta aset pajak tangguhan pada manajemen keuntungan. Perusahaan menggunakan manajemen laba unutk meningkatkan tingkat laba atau menurunkan beban pajak. Semakin besar perusahaan maka makin besar kemungkinan terjadinya manajemen laba.
\end{abstract}


Kata Kunci; Pajak, Aset Pajak, Perusahaan, Manajemen Laba

\section{DASAR PEMIKIRAN}

Setelah melewati satu periode operasional, perusahaan akan membentuk suatu laporan keuangan sebagai laporan kinerjanya. Laporan tersebut akan menjadi dasar informasi untuk berbagai kepentingan bagi dari pihak internal maupun pihak eksternal. Tahun 2003, Suwardjono berpendapat bahwa yang dimaksud sbeagai pihak internal adalah bagian internal perusahaan yang membutuhkan informasi laporan keuangan adalah manajemen, sedangkan pihak eskternal terdiri dari kreditor, investor, pemasok, pelanggan, lembaga pendidikan, lembaga pemerintah, serta masyarakat umum. Ardiansyah \& Farid (2021) menyatakan dalam tanggung jawab yang dilaksnaakan oleh manajemen perusahaan untuk melakukan operasi laporan keuangan tapi manajemen seringnya melaksanakan praktik manipulasi laporan keuangan agar memperlihatkan seolah keadaan perusahaan baik.

Penggunaan komponen laba merupakan komponen paling mudah digunakan sebagai bahan pertimbangan. Wiryandari dan Yulianti (2009) menyebutkan keuntungan yang bisa memberi cerminan keberlanjutan keuntungan di masa depan adalah keuntungan yang punya kualitas, yang memberi cerminan kinerja keuangan perusahaan secara real dengan ditentukan komponen akrual dan kas". Berdasarkan laba tersebut juga, besaran bonus akan ditetapkan. Pada tahun 2003, Kusuma et al menyatakan bahwa fenomena tersebut seringkali memberi motivasi manajer dalam melakukan manajemen keuntungan dalam memberi pengaruh angka laba.

Di Indonesia terdapat kasus-kasus perusahaan yang melaksanakan manajemen keuntungan dalam rangka memperbesar laporan labanya. Kasus terbaru yang cukup mendapat banyak perhatian adalah kasus dari PT Garuda Indonesia. Perusahaan plat merah tersebut terbukti melakukan kecurangan dengan memanipulasi laporan keuangan yang dimana laba bersih tidak lagi mencerminkan kondisi sesungguhnya.

Otoritas Jasa Keuangan (OJK) menemukan bahwa laba bersih yang dibukukan RP 11,33 mencurigakan. Hal ini karena pada periode sebelumnya, laporan keungan periode 2017 PT Garuda Indonesia mengalami kerugian senilai Rp 3 Triliun. Keuntungan dari 
ISLAMIC BANKING: Jurnal Pemikiran dan Pengembangan Perbankan Syariah, Volume 7 Nomor 2 Edisi Februari 2022

kerjasama dengan PT Mahata Areo Teknologi diakibatkan maskai PT Garuda Indonesia memiliki piutang atas perusahaan tersebut.

Salah satu dari stakeholder laporan keuangan adalah otoritas perpajakan. Bagi otoritas pajak, informasi laporan keuangan dibutuhkan untuk menentukan besaran pajak terhutang. Semenjak 1984, Indonesia telah menerapkan self assessment system untuk system pemungutan pajaknya. Sistem ini menyerahkan kewenangan atas penghitungan pajak kepada wajib pajak itu sendiri. Dengan demikian, manajemen perusahaan memiliki otoritas untuk menghitung sendiri besaran pajak yang harus dibayarkan berdasarkan laporan tersebut.

Pemerintah mengharapkan peningkatan tax compliance dan pembayaran sukarela. Namun, manajemen perusahaan yang oportunistik dapat menggunakan system ini untuk memanajemen keuntungan. Dalam perihal manajemen laba, pendapat dari Brian dan Martani (2014) dapat melakukan:

"Perusahaan dapat melakukan dua cara untuk mengecilkan total pembayaran pajak yakni mengecilkan nilai pajak melalui tetap menyesuaikan aturan pajak yang ada (penghindaran pajak) atau mengecilkan nilai pajak melalui tindakan yang tak bersesuaian dengan UU perpajakan (menggelapkan pajak)".

Perbedaan aturan antara akuntansi dan pajak dapat digunakan sebagai metode untuk memanajemen keuntungan. Konformitas antara kedua aturan tersebut cukup mustahil dikarenakan perbedaan kepentingan antara akuntansi dan perpajakan. Dengan demikian potensi terjadi tax dispute akan cukup besar. Bagi administrasi perpajakan hal ini akan mengurangi tingkat efisiensi dari pemasukan pajak karena biaya yang pemungutan perpajakan akan semakin besar.

TABEL 1

Kasus Sengketa Pajak Tahun 2014-2020

\begin{tabular}{|c|c|c|c|c|c|c|c|c|}
\hline Keterangan & 2014 & 2015 & 2016 & 2017 & 2018 & 2019 & 2020 & TOTAL \\
\hline $\begin{array}{c}\text { Direktorat } \\
\text { Jendral } \\
\text { Pajak }\end{array}$ & 7.386 & 7.669 & 7.109 & 5.553 & 7.813 & 12.882 & 14.660 & 63.072 \\
\hline
\end{tabular}

Sumber : Data diolah dari Pengadilan Pajak 


\section{VARIABEL PENELITIAN}

\section{Aset Pajak Tangguhan}

Implementasi peraturan akuntansi di bidang pajak dan komersial akan menghasilkan laporan akhir yang berbeda. Perbedaan tersebut dihasilkan dari perbedaan dalam hasil dasar aturan yang mendasari keduanya. Perbedaan tersebut dapat dibagi menjadi dua tipe:

1. Perbedaan Permanen (Waluyo.2010):

Perbedaan tetap (permanent difference) muncul menjadi akibat keberadaan beda pengakuan beban dan pendapatan pada pelaporan pajak/ fiscal dan komersial. Akibatnya berefek pada laba komerisal serta laba fiskal yang jadi dasar hitungan pajak yang terhutang.

2. Perbedaan Temporer (Suandy.2008)

Beda waktu atau beda temporer yaitu beda yang sebabnya adalah terdapat beda metode dan waktu pengakuan pemasukan dan beban khusus sebagaimana standar akuntansi keuangan dan aturan perpajakan yang ada.

Contoh Dari perbedaan temporer adalah sebagai berikut:

a. Metode penyusutan

Metode diakui oleh peraturan fiskal yaitu metode saldo menurun dan metode garis lurus. Sedangkan secara akuntansi, terdapat lebih banyak metode depresiasi yang dapat dipilih oleh perusahaan.

b. Penyisihan piutang tak tertagih

Terdapat perbedaan pengakuan piutang tak tertagih menurut akuntansi dan perpajakan. Menurut PSAK, piutang tak tertagih dapat dikurangkan dari pendapatan hingga membuat laba semakin kecil. Menurut peraturan perpajakan beban piutang tak tertagih untuk entitas non lembaga keuangan memiliki persyaratan tertentu agar dapat dikurangkan dari penghasilan kena pajak. Persyaratan tersebut adalah pembebanan di laporan keuangan, penyerahan perkara beban tak tertagih tersebut ke pengadilan negara, c. Rugi laba selisih kurs

Peraturan fiskal mengakui kurs yang dikeluarkan oleh menteri perekonomian. Di sisi lain, peraturan akuntansi mengakui kurs yang dikeluarkan dari Bank Indonesia. 
ISLAMIC BANKING: Jurnal Pemikiran dan Pengembangan Perbankan Syariah, Volume 7 Nomor 2 Edisi Februari 2022

Perbedaan perlakuan dan pengakuan tersebut mengakibatkan munculnya kewajiban kepada perusahaan untuk membentuk koreksi fiskal. Koreksi fiskal yang dilakukan dapat dibagi menjadi koreksi fiscal secara negatif dan koreksi fiscal secara positif. Koreksi fiscal positif akan mengakibatkan penambahan laba fiscal perusahaan. Sedangkan, koreksi negative akan mengurangi laba fiscal perusahaan. Setelah melewati proses koreksi fiscal akibat perbedaan peraturan akuntansi dan perpajakan maka perusahaan akan mendapatkan komponen laba fiscal sebelum pajak.

Pajak tangguhan sendiri terdiri dari dua macam:

1. Beban Pajak Tangguhan

Djamaludin (2008) Selisih negatif antara keuntungan akuntansi dan keuntungan fiskal menyebabkan munculnya koreksi negative yang menghadirkan adanya beban pajak tangguhan. Selain itu, terdapat juga pendapat dari Waluyo (2012) yang menyatakan bahwa:

Beban pajak (tax expense) yaitu total agregat pajak saat ini(current tax) dan pajak tangguhan (deferred tax) yang dihitung dalam hitungan untung-rugi akuntansi dalam suatu periode berjalan menjadi penghasilan atau beban. Pajak saat ini (current tax) yaitu total pajak penghasilan terutang atas penghasilan kena pajak dalam periode atau 5 tahun pajak berjalan, sedangkan pajak tangguhan adalah jumlah pajak penghasilan terutang untuk periode mendatang sebagai akibat adanya perbedaan temporer kena pajak."

\section{Aset Pajak Tangguhan}

Berdasarkan Waluyo (2008) asset pajak tangguhan yang terjadi apabila perbedaan waktu yang menyebabkan koreksi positif yang berakibat beban pajak menurut akuntansi komersial yang kurang dari beban pajak berdasar UU pajak.

\section{Ukuran Perusahaan}

Ukuran perusahaan dapat digunakan untuk menjadi salah satu indicator dari manajemen laba. Penelitian Kim, Liu dan Rhee (2003) menemukan adanya hubungan dari ukuran perusahaan dan kemungkinan adanya manajemen laba. Sudarmadji dan Sularto (2007) menyatakan bahwa total asset, penjualan dan kapitalisasi pasar 
merupakan pernyataan mengenai ukuran perusahaan sesungguhnya. Berdasarkan pernyataan tersebut, maka total aset dapat dijadikan alat ukur dari ukuran perusahaan untuk melihat hubungan dengan manajemen laba.

\section{Manajemen Laba}

Manajemen laba terlaksna saat manajemen memakai manajemen finansial, pelaporan dan transaksi yang dapat melakukan pengubahan laporan finansial dalam rangka mengelabui para pemilik kepentingan mengenai performa ekonomi perusahaan ataupun dalam rangka mempengaruhi hasil dari angka yang dilaporkan Healy \& Wahlen (1999). Terdapat juga pendapat dari Aditama dan Anna (2014) yang menyatakan bahwa manajemen laba adalah usaha dari pihak manajemen dalam rangka mengintervensi proses menyusun laporan keuangan yang tujuannya agar memberi keuntungan dirinya sendiri, yaitu pihak perusahaan tersebut.

Berdasarkan pendapat dari Scott (2003), motivasi dari manajemen laba adalah akibat dari rencana bonus, hutang dan biaya politik. Manajemen laba terdiri dari beberapa macam yaitu :

\section{a. Taking a Bath}

Pola ini dipakai ketika perusahaan di keadaan tertekan atau sedang terjadi reorganisasi seperti penggantian CEO yang baru. Manajemen laba pada pola ini akan menjadi sangat ekstrim baik secara positif maupun negative jika dibandingkan terhadap laba di periode sesudah atau sebelumnya.

Teknik manajemen laba ini mengakui ada biaya dalam periode selanjutnya dan kerugian dalam periode berjalan saat ada kondisi yang tak memberi untung dan tak dapat dihindari selama periodenya berlangsung. Sebagai akibatnya beberapa aset akan dihapuskan dan juga pengakuan beban estimasi biaya di masa depan. Akibanya, laba dalam periode selanjutnya bisa jada lebih tinggi dibanding semestinya.

\section{b. Minimisasi laba}

Pola ini dipakai saat perusahaan punya laba tinggi. Ketika kondisi tersebut terjadi sehingga nantinya banyak perhatian yang ditujukan ke perusahaan. Manajemen 
ISLAMIC BANKING: Jurnal Pemikiran dan Pengembangan Perbankan Syariah, Volume 7 Nomor 2 Edisi Februari 2022

terkadang tidak menginginkan perhatian tersebut dikarenakan berbagai macam hal. Untuk menghindarinya, manajemen akan melakukan penurunan laba.

Manajemen untuk meminimalisasi laba sebenarnya mirip dengan metode Taking a Bath, namun dilakukan secara lebih halus hingga hasilnya tidak seekstrim Taking a Bath. Jika laba yang akan dating diperkirakan akan rendah, maka laba tahun sebelumnya bisa dimanfaatkan. Manajemen dapat menghilangkan barang modal serta aset tidak punya wujud, pemberian beban pengeluaran iklan, R\&D dan lainnya.

\section{c. Maksimalisasi Laba}

Jika laba menjadi rendah, manajemen akan berusaha untuk mencoba meningkatkan laba yang tertera di laporan keuangan. Teknik ini dilakukan untuk tujuan mendapatkan laba maksimum. Teknik manajemen pola yang dipakai saat manajer ingin kenaikan bonus. Kondisi lainnya adalah ketika perusahaan dipertemukan dengan perjanjian hutang tinggi dan tak bisa dibayar. Pola tersebut dapat dilihat dengan perusahaan mempercepat pencatatan atas pendapatan, melakukan penundaan atas biaya dan melakukan pemindahan atas biaya untuk periode selanjutnya. Angka laba akan jadi melebihi kondisi sesungguhnya.

\section{d. Perataan laba (Income Smoothing)}

Pola yang dipakai perusahaan dalam rangka mengantisipasi kondisi yang nantinya ditemuni perusahaan. Manajemen akan melakukan cara ini untuk membuat laba akuntansi yang stabil dari suatu period ke periode berikutnya. Pihak manajemen akan secara sengaja membuat laba turun atau naik. Hal ini dilakukan dalam rangka meminimalkan perubahan yang ekstrem di dalam pelaporan laba sehingga perusahaan akan terlihat stabil.

Pada kondisi pendapatan relative rendah dan pendapaian laba di masa depan akan relative tinggi maka manajemen akan melakukan pendekatan akuntansi yang dapat meningkatkan akrual diskresioner pada saat ini. Ketika kondisi yang terjadi adalah sebaliknya maka manajemen dapat menggunakan metode akuntansi yang menurunkan nilai akrual diskresioner. 
Manajemen percaya bahwa investor lebih menyukai perusahaan yang mampu menciptakan laba yang relative stabil. Oleh karena itu manajemen akan berupaya untuk menjaga tingkat fluktuatif tetap stabil. Hingga manajemen akan menabung keuntungan saat ini untuk mengantisipasi kondisi pendapatan rendah di masa depan.

\section{Landasan Teoritis}

\section{a. Teori Pemungutan Pajak Efisien}

Salah satu aspek yang harus dipenuhi oleh otoritas perpajakan dalam pemungutan pajak adalah efisiensi. Pengorbanan, baik berupa uang, waktu dan tenaga, yang dikeluarkan harus lebih kecil daripada pajak yang akan diambil. Ketika kondisi tersebut dapat tercapai maka pemungutan pajak yang efisien dapat tercapai dengan baik.

Pada dasarnya, pajak yang dipungut akan menjadi sumber pemasukan negara dalam menjalankan tugas dan fungsi negara. Namun, apabila otoritas pajak tidak berhasil menekan biaya administrasi hingga menjadi lebih kecil dari pemasukan maka fungsi administrasi pajak tidak berjalan efisien.

\section{a. Second Best Theory}

Hukum pajak merupakan suatu rule of the tax game atau peraturan main dari perpajakan. Otoritas pajak dan wajib pajak akan bermain di dalam aturan ini. "Dalam permainan ini pula, dikenal beberapa teori yang disebut dengan The First Best, The Second Best, dan The Third Best" (Ng, 1979, hal. 217-243; 2017, hal. 155; Hoff, 2000, hal. 1463-1464).

Teori The First Best memiliki konstrain berupa kelangkaan sumber daya yang membatasi hasil ekonomi. Untuk Teori The Second Best, konstrain tersebut berupa monopoli dan eksternalitas yang membatasi hasil ekonomi. Apabila kedua teori sebelumnya tidak dapat direalisasikan maka teori The Third Best akan dipilih.

Teori ini berfokus kepada kondisi dimana kondisi optimum di dalam suatu model ekonomi tidak dapat dicapai yang dapat mengakibatkan kondisi ekulibrium yang ada akan berubah. Teori tersebut memiliki implikasi penting di dalam memahami banyak kebijakan pemerintah (Suranovic, 2012). Masalah yang dapat sering ditemukan dalam 
ISLAMIC BANKING: Jurnal Pemikiran dan Pengembangan Perbankan Syariah, Volume 7 Nomor 2 Edisi Februari 2022

teori ini adalah ketika pareto optimal tidak dapat tercapai akibat terdapatnya konstrain di dalam system ekuilibrium dan distorsi.

\section{Pengembangan Hipotesis}

\section{a. Pengaruh Aset Pajak Tangguhan terhadap Manajemen Laba}

Pada tahun 2007, Suranggane menyatakan bahwa selisih positif diantara akuntansi serta keuntungan fiscal menyebabkan dialaminya koreksi positif yang menjadikan adanya aset pajak tangguhan. Laba akuntansi yang lebih besar akan mendorong manajemen perusahaan untuk menunda pajak terutang untuk periode yang akan datang. Penelitian dari Suranggane (2007) menyatakan yaitu aset pajak tangguhan dibuat perwakilan menjadi indicator dari manajemen keuntunan yang dilaksanakan perusahaan.

Berdasarkan pernyataannya, maka dapat diambil suatu ekspektasi bahwa terdapat peranan aset pajak tangguhan terhadap manajemen keuntungan. Hipotesa yang dapat dibentuk yaitu diantaranya:

\section{H1: Aset Pajak Tangguhan Berpengaruh Terhadap Manajemen Laba Pengaruh Ukuran Perusahaan Terhadap Manajemen Laba}

Semakin besar perusahaan maka semakin besar pula dana yang disuntikan oleh para investor kepada perusahaan. Dengan dana tersebut kebutuhan pendanaan untuk menjadi modal dasar kegiatan sehari-hari. Bagi manajemen, hal ini merupakan suatu tekanan dikarenakan semakin banyak investor yang memiliki kepentingan terhadap perusahaan. Hipotesis yang dapat diambil adalah :

\section{H2 : Ukuran Perusahaan Berpengaruh Terhadap Manajemen Laba}

\section{METODE PENELITIAN}

Penelitian ini alkan memakai pendekatan campuran. Pendekatan ini merupakan penggabungan dua pendekatan yakni pendekatan kuantitatif dan kualitatif. Menurut Creswell (2015) Penelitian campuran merupakan sebuah prosedur dalam rangka melakukan pengumpulan, analisa, dan menggabungkan metode kualitatif dan kuantitatif 
pada sebuah penelitian ataupun rangkaian penelitian dalam rangka paham dengan masalah penelitian (p. 1088).

\section{a. Pendekatan Kuantitatif}

Untuk Sampel data kuantitatif menggunakan data sekunder berupa laporan keuangan. Penelitian ini menggunakna purposive sampling atas perusahaan manufaktur yang listing di BEI. Terdapat beberapa kriteria yang harus dipenuhi agar bisa dimasukan ke dalam penelitian ini. Persyaratan tersebut adalah:

1) Memiliki data komponen aset pajak tangguhan untuk periode 2018-2020.

2) Memiliki data komponen ukuran perusahaan untuk periode 2018-2020.

3) Memiliki data komponen manajemen laba untuk periode 2018-2020.

4) Menggunakan mata uang Rupiah.

5) Data tersedia di situs idx.com

Untuk membantu dalam melakukan pemrosesan data, aplikasi SPSS 25 akan digunakan. Penelitian yang dilakukan nantinya memakai regresi linier berganda. Data yang dikumpulkan akan terlebih dahulu dilakukan uji klasik untuk mengecek kelayakan dalam penelitian. Untuk melakukan uji asumsi klasik, terdapat beberapa pengujian yang akan dilakukan kepada data. Pengujian klasik itu diantaranya:
a) Uji Normalitas
b) Uji Heteroskedistisitas
c) Uji Multikolonieritas
d) Uji Autokorelasi

Setelah data teruji layak untuk diteruskan, metode regresi linier ganda sebagai metode statistic. Regresi linier ganda dapat dipakai dalam rangka mengetahui hubungan antara lebih dari dua variable. Aplikasi yang digunakan untuk melakukan proses penghitungan adalah SPSS. Analisis regresi linier memiliki tujuan dalam rangka tahu besarnya keberpengaruhan suatu variable terikat dapat diprediksikan oleh variable bebas.

Pengaruh variabel independen

$$
\mathrm{Y}=\mathrm{a}+\mathrm{b}_{1} \mathrm{X}_{1}+\mathrm{b}_{2} \mathrm{X}_{2}+\mathrm{e}
$$

$\mathrm{Y} \quad=$ Manajemen Laba 
ISLAMIC BANKING: Jurnal Pemikiran dan Pengembangan Perbankan Syariah, Volume 7 Nomor 2 Edisi Februari 2022

A $=$ Constanta

b1,2 = Koefisien variable

$\mathrm{X} 1$ = Aset Pajak Tangguhan

$\mathrm{X} 2$ = Ukuran Perusahaan

$\mathrm{E}=$ error

\section{b. Definisi Operasional Variabel dan Pengukuran}

\section{1) Aset Pajak Tangguhan}

Adapun rumus untuk mencari rasio aktiva pajak tangguhan adalah sebagai berikut.Untuk menghitung berapa jumlah aset pajak tangguhan, dapat menggunakan rumusan sebagai berikut:

$$
A P \text { it }=\frac{\Delta \text { Aset Pajak Tangguhan it }}{\text { Aset Pajak Tangguhan } t}
$$

\section{2) Ukuran Perusahaan}

Untuk bisa mengukur variable ukuran perusahaan, dapat digunakan rumusan sebagai berikut:

$$
\text { Size }=\text { Ln Total Aset }
$$

Size $=$ Ukuran Perusahaan

LnTotal Aset $=\log$ natural dari asset total perusahaan

\section{c. Pendekatan Kualitatif}

Setelah selesai melakukan analisa-analisa atas data kuantitas maka langkah selanjutnya adalah melakukan pendekatan kualitatif. Metode yang akan digunakan untuk melakukan pendekatan kualitatif adalah dengan pendekatan procedural eksplanatoris. Adapun, strategi procedural eksplanatoris adalah sebagai berikut (Creswell.2013): 


\section{Gambar 1}

\section{Procedural Eksplanatoris}
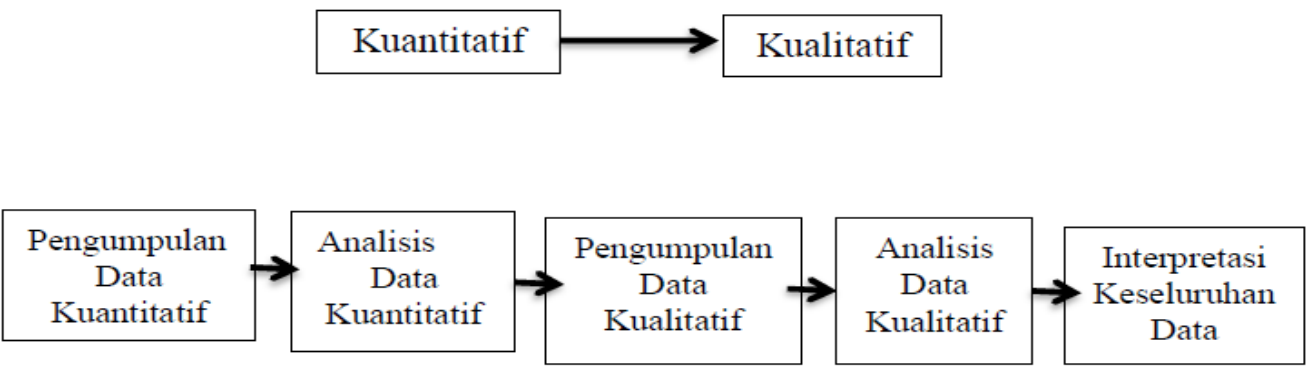

Sumber: Creswell 2013. Research Design Pendekatan Kualitatif, Kuantitatif, dan Mixed

\section{d. Narasumber}

Narasumber pada penelitian yang dilakukan yaitu dari praktisi pajak dan juga pegawai dari Direktorat Jenderal Pajak. Praktisi pajak akan dipilih yang memiliki sertifikasi akuntansi public. Kedua pihak tersebut telah memiliki pengalaman dalam perpajakan

\section{e. Variabel Dependen}

1. Manajemen Laba

Dalam peneitian ini manajemen keuntungan dilakukan pengukuran melalui pendekatan distribusi laba yang hitungannya memakai rumus di bawah ini :

$$
\text { Manajemen Laba }=\frac{(\text { Net Income } t-\text { Net Income } t-1)}{\text { Market value equity }(t-1)}
$$

Untuk penghitungan Market Value Equity bisa dilakukan pengukuran melalui formula di bawah ini:

MVE = Saham yang Beredar $\mathrm{x}$ Harga Saham 
ISLAMIC BANKING: Jurnal Pemikiran dan Pengembangan Perbankan Syariah, Volume 7 Nomor 2 Edisi Februari 2022

\section{HASIL DAN PEMBAHASAN}

\section{Uji Statistik Deskriptif}

TABEL 2

Descriptive Statistics

\begin{tabular}{lc|r|r|r|r} 
& $\mathrm{N}$ & \multicolumn{1}{c}{ Minimum } & Maximum & \multicolumn{1}{c}{ Mean } & Std. Deviation \\
\hline Aset Pajak Tangguhan & 150 & -35.65079 & 0.89445 & -0.3478105 & 3.04067233 \\
\hline Ukuran Perusahaan & 150 & 20.92435 & 32.72561 & 28.3247501 & 1.84592006 \\
\hline Manajemen Laba & 150 & -14.98559 & 4.54753 & -0.1556357 & 1.96626732 \\
\hline Valid N (listwise) & 150 & & & & \\
\hline Sulise & & & & \\
\hline
\end{tabular}

Sumber: Olahan SPSS

Uji deskripstif dapat digunakan untuk melihat nilai terendah, mean dan tertinggi dari variable yang digunakan dalam penelitian ini. SPSS dapat digunakan untuk mendapatkan nilai-nilai deskriptif yang dicari.

Untuk variable asset pajak tangguhan, nilai minimum adalah -35.65079 , nilai maksimum adalah 0.89445 dan nilai mean -0.3478105. nilai standar deviasi memiliki nilai 3.04067233. Nilai standar deviasi tersebut menunjukan bahwa sebaran variable ini cukup besar.

Nilai ukuran perusahaan memiliki nilai minimum 20.92435, nilai tertinggi 32.72561 dan nilai mean 28.3247501. Nilai standar deviasi dari variable ini adalah senilai 1.84592006. nilai tersebut menunjukan bahwa sebaran dari variable ini kecil.

Nilai manajemen laba memiliki nilai terkecil -14.98559, nilai maksimum 4.54753 dan nilai mean -0.1556357. nilai standar deviasi dari variable manajemen laba dalah senilai 1.96626732. Besaran nilai tersebut menunjukan bahwa sebaran dari variable ini kecil.

\section{Uji Hipotesis}

\section{Tabel 3}

\section{Hasil Analisis Linier Regresi Berganda Coefficients}

\begin{tabular}{|c|c|c|c|c|c|c|}
\hline \multirow{2}{*}{\multicolumn{2}{|c|}{ Model }} & \multicolumn{2}{|c|}{$\begin{array}{l}\text { Unstandardized } \\
\text { Coefficients }\end{array}$} & \multirow{2}{*}{$\begin{array}{c}\text { Standardized } \\
\text { Coefficients } \\
\text { Beta }\end{array}$} & \multirow[b]{2}{*}{$\mathrm{t}$} & \multirow[b]{2}{*}{ Sig. } \\
\hline & & B & Std. Error & & & \\
\hline \multirow[t]{2}{*}{1} & (Constant) & -0.993 & .472 & & -2.104 & .038 \\
\hline & $\begin{array}{l}\text { Aset Pajak } \\
\text { Tangguhan }\end{array}$ & 0.201 & .066 & .282 & 3.025 & .003 \\
\hline
\end{tabular}


Ukuran Perusahaan

0.037

.017

.204
2.190 .031

a. Dependent Variable: Manajemen Laba

Nilai koefisien regresi variabel Aset Pajak Tangguhan $\left(\mathrm{X}_{1}\right)$ adalah senilai 0.201. Setiap peningkatan Aset Pajak Tangguhan senilai 1 satuan, sehingga nantinya melakukan peningkatan Manajemen keuntungan senilai 0.201 melalui asumsi yaitu variabel bebas lain punya nilai tetap. Kondisi tersebut mengindikasikan yaitu variabel Manajemen Laba $\left(\mathrm{X}_{1}\right)$ punya keberpengaruhan positif pada Manajemen Laba $(\mathrm{Y})$.

Nilai koefisien regresi variabel Ukuran Perusahaan $\left(X_{2}\right)$ yaitu senilai 0.037. Setiap peningkatan Ukuran Perusahaan senilai 1 satuan, sehingga nantinya membuat bertambahnya Manajemen Laba senilai 0.037 melalui asumsi yaitu variabel bebas lain dengan nilai tetap. Hal tersebut mengindikasikan yaitu variabel Ukuran Perusahaan $\left(\mathrm{X}_{2}\right)$ punya keberpengaruhan positif pada Manajemen Laba (Y).

Tabel 4.9 kolom Sig. pada variabel Aset Pajak Tangguhan nampak nilai Significance senilai 0.003, sebab nilai signifikansi (2-tailed) kurang dari 0.05 sehingga bisa dianggap signifikan. Uji melalui uji t yaitu, nilai tabel t dalam alpha 0.05 (Two tail) yaitu 1.982. Padahal nilai $\mathrm{t}$ hitung dalam Tabel tersebut senilai uji $\mathrm{t}=3.025$. Artinya $t_{\text {hitung }}>\mathrm{t}_{\text {tabel }}$ sehingga $\mathrm{H}_{1}$ diterima, maka mengindikasikan Aset Pajak Tangguhan punya keberpengaruhan positif dan signifikan pada manajemen keuntungan perusahaan sektor Manufaktur di BEI 2018-2020.

\section{HASIL WAWANCARA}

Pada dasarnya manajemen laba dapat dilakukan selama masih memenuhi koridor pajak dan akuntansi. Manajemen pajak bisa berbentuk membesarkan laba perusahaan atau mengecilkan beban dari pajak yang harus dibayarakan. Jika ada perbedaan antara hasil akuntansi dan perpajakan maka perlu untuk diadakan koreksi. Jika ditemukan indikasi adanya penghindaran atau penggelapan pajak yang terbukti melanggar hokum maka WP harus siap untuk menerima konsekuensinya.

Setiap WP terutama yang berbentuk PKP harus membuat pencatatan atau pembukuan. WP dapat memilih pembukuan tersebut dapat berbasis accounting lead ataupun tax lead. Funsgi pembukuan tersebut pada dasarnya adalah untuk membantu 
ISLAMIC BANKING: Jurnal Pemikiran dan Pengembangan Perbankan Syariah, Volume 7 Nomor 2 Edisi Februari 2022

menentukan berapa sebenarnya besaran pajak yang terhutang oleh WP pada suatu periode.

Peraturan pajak dan akuntansi berbeda dikarenakan kepetingan pembuat peraturan tersebut berbeda pula. Dalam melaksanakan usaha, PKP harus mengikuti aturan akuntansi baik PSAK ataupun IFRS. Laporan tersebut akan direkonsiliasi dengan aturan dari segi perpajakan. Jika WP tidak setuju dengan peraturan pajak maka bisa berpotensi tax dispute yang berakibat penurunan tingkat efisiensi administrasi pajak. Dengan adanya dispute, biaya-biaya yang harus dikeluarkan oleh otoritas pajak akan menjadi semakin besar.

Untuk bisa menghindari tax dispute, berbagai tingkat pelayanan dari penyuluhan hingga pemeriksaan dapat melakukan himbauan untuk memberikan pemahaman kepada WP terutama perihal penyusutan aset yang menjadi dasar manajemen laba pada penelitian ini. UU perpajakan yang ada saat ini juga bisa digunakan untuk system antitax avoidance. Otoritas perpajakan sendiri juga akan memantau terus perkembangan di administrasi pajak di lapangan. Jika dilihat bahwa tingkat penghindaran pajak yang melawan hukum meningkat maka DJP akan melakukan peningkatan pengawasan dan pemeriksaan untuk menanggulanginya.

\section{SIMPULAN}

Hasil akhir didapatkan dari hasil proses analisis regresi linier ganda memakai SPSS 25. Setelah dilakukan uji asumsi klasik serta uji hipotesis sehingga data dapat diproses lebih lanjut untuk akhirnya dibuat kesimpulan sebagai berikut:

a. Aset pajak tangguhan yang diproksikan pada penyusutan aset tetap punya keberpengaruhan positif terhadap manajemen laba.

Aset pajak tangguhan dengan diproksikan penyusutan atas aset pajak dapat punya keberpengaruhan pada manajemen keuntungan suatu perusahaan. Perbedaan antara peraturan akuntansi dana perpajakan akan mendorong tindakan opportunistic dari manajemen untuk mengejar tujauan pribadinya.

b. Ukuran Perusahaan yang diproksikan terhadap aset tetap berpengaruh positif terhadap manajemen laba. 
210 Muhammad Faisal Akbar Ibrahimy \& Gunadi, Perspektif Pajak Atas Pengaruh Aset Pajak..........

Ukuran perusahaan yang menggunakan pengukuran total aset punya keberpengaruhan pada kemungkinan terjadinya manajemen laba. Besarnya perusahaan akan memiliki jumlah aset yang lebih banyak. Jumlah aset yang semakin besar akan menjadi celah untuk melakukan tindakan oportunistik bagi manajemen perusahaan.

Pada dasarnya, penggunaan manajemen laba di dalam perusahaan tidak menjadi suatu masalah selama masih berada di jalur hokum perpajakan. Peraturan akuntansi mengizinkan perusahaan untuk menerapkan suatu pilihan metode penyusutan yang dirasakan sesuai dengan manajemen aset perusahaan. Namun, perusahaan harus konsisten dalam penggunaan metode penyusutannya.

Peraturan akuntansi dan perpajakan tidak akan pernah bisa menjadi sama dikarenakan tujuan keduanya berbeda. Untuk mengatasi perbedaan hasil laporan akuntansi dan perpajakan maka dapat diatasi dengan rekonsiliasi fiscal. Namun, apabila masih terdapat perbedaan pandangan antara kedua belah pihak bisa melakukan mediasi. Jika perbedaan pendapat tetap ada maka bisa dibawa ke ranah pengadilan. Hal ini tentu akan menurunkan tingkat efisiensi dari administrasi perpajakan. 
ISLAMIC BANKING: Jurnal Pemikiran dan Pengembangan Perbankan Syariah, Volume 7 Nomor 2 Edisi Februari 2022

\section{DAFTAR PUSTAKA}

Kusuma, Hadri dan Wigina Ayu Udiana Sari.2003. Manajemen Laba oleh Perusahaan Pengakuisisi Sebelum dan Sesudah Merger dan Akuisisi di Indonesia \|.Jurnal Akuntansi dan Auditing Indonesia .Vol. 7.No. 1.Juni.hal: 21-36.

Hartono, Jogiyanto. 2008. Teori Portofolio dan Analisis Investasi Edisi Kelima. BPFE. Yogyakarta.

Suwardjono.2003. Teori Akuntansi. Yogyakarta: BPFE.

Brian, Ivan \& Martani, D, (2014) Analisis pengaruh penghindaran pajak dan kepemilikan keluarga terhadap waktu pengumuman laporan keuangan tahunan perusahaan. Simposium Nasional Akuntansi XVII.

Ardiansyah,M \& Farid,A.S.2021. The Effect of Tax Planning, Deffered Tax Expenses, and Company Size on Income Management. Open Journal Systems. Vol.15 No.6 Januari 2021

Creswell, John W. 2015. Penelitian Kualitatif \& Desain Riset. Yogyakarta : Pustaka Pelajar.

Creswell W. John. 2013. Research Design Pendekatan Kualitatif, Kuantitatif, dan Mixed. Yogyakarta : Pustaka Pelajar.

Suranggane, Zulaikha. 2007.Analisis Aktiva Pajak Tangguhan dan Akrual Sebagai Prediktor Manajemen Laba: Kajian Empiris Pada Perusahaan Manufaktur Yang Terdaftar di BEJ". Jurnal Akuntansi dan Keuangan Indonesia Vol.4, No.1, Hal 77-94.

Suranovic, S.2012. Policy and Theory of International Trade, version 1.0. Creative Commons.

Hoff, K. (2000). Second and Third Best Theories. In J. Michie, Reader's Guide to the Social Sciences, Volume 1 (pp. 1463-1464). Abingdon: Routledge - Taylor \& Francis.

Healy, Paul M. and J.M. Wahlen. (1999). A Review Of The Earnings Management Literature And Its Implications For Standard Setting. Accounting Horizons 13, p. 365-383.

Aditama, Ferry dan Anna Purwaningsih (2014), Pengaruh Perencanaan Pajak terhadap Manajemen Laba pada Perusahaan Non Manufaktur yang terdaftar di Bursa Efek Indonesia, Fakultas Ekonomi Universitas Atma Jaya Yogyakarta, Modus Vol. 26

Ardi Murdoko Sudarmadji dan Lana Sularto, 2007. "Pengaruh Ukuran Perusahaan, Profitabilitas, leverage, dan Tipe Kepemilikan Perusahaan Terhadap Luas 
212 Muhammad Faisal Akbar Ibrahimy \& Gunadi, Perspektif Pajak Atas Pengaruh Aset Pajak...........

Voluntary Disclosure Laporan Keuangan Tahunan", Proceeding PESAT, Volume 2.

Kim, Y., Liu, C., dan Rhee, S.G. 2003. The Effect of Firm Size on Earning Management, Journal College of Business Administration University of Hawai, 6: $1-30$.

Waluyo, (2008), Perpajakan Indonesia, Salemba Empat, Jakarta.

Djamaludin, dkk. 2008. Analisis Pengaruh Perbedaan Antara Laba Akuntansi Dan Laba Fiskal Terhadap Persistensi Laba, Akrual, Dan Arus Kas Pada Perusahaan Perbankan Yang Terdaftar Di Bursa Efek Jakarta. Jurnal Riset Akuntansi Indonesia Vol. 11 